Article

\title{
Impossible Subjects: LGBTIQ Experiences in Australian Pentecostal-Charismatic Churches
}

\author{
Mark A. C. Jennings
}

School of Arts, Murdoch University, 90 South Street, Murdoch 6150, Australia; m.jennings@murdoch.edu.au

Received: 12 December 2017; Accepted: 7 February 2018; Published: 9 February 2018

\begin{abstract}
This paper is the product of in-depth interviews with 20 Lesbian, Gay, Bisexual, Transgender, Intersex, and Queer (LGBTIQ) people who identify, or formerly identified, as members of Pentecostal-Charismatic Christian (PCC) churches. Interviewees typically found themselves confronted with a number of choices (not necessarily mutually exclusive): remain closeted, come out but commit to remaining celibate, undergo "SOCE" (Sexual Orientation Conversion Efforts) therapy, or leave. Most left their churches, often after agonising attempts to reconcile their faith and their sexuality. Several of the practices adopted by Australian PCC churches exclude LGBTIQ people from full participation in their own congregations, rendering them "impossible subjects." Australian Pentecostalism's surprisingly egalitarian history, wherein the spiritually authorised ministry of women was both recognised and celebrated, suggests another, more inclusive way forward in regard to this vexed issue.
\end{abstract}

Keywords: LGBTIQ; Pentecostal-Charismatic Christianity; Australia; Australian Pentecostal history; Sexual Orientation Change Efforts; Inclusive faith

\section{Introduction}

This paper emerged from the "Two Different Worlds" project, initiated by the author in 2015 in order to find out more about the experiences of Lesbian, Gay, Bisexual, Transgender, Intersex, and Queer (LGBTIQ) people who attend or have attended Pentecostal-Charismatic Christian (PCC) churches in Australia. ${ }^{1}$

Several of those interviewed reported being in ministry or volunteering roles in their congregations. Often, they had verified spiritual experiences and exercised charismatic gifts, such as glossolalia, inspired speech, or healing. However, if they wished to remain in these roles, they were confronted with a dilemma - continue to conceal their LGBTIQ status, or come out and risk losing their ministry, and maybe more. In rare cases, LGBTIQ people in PCC churches were referred to a version of Sexual Orientation Change Efforts (SOCE), ranging from "conversion" therapy to exorcism.

Some LGBTIQ people who were able to stay in their PCC churches described supportive relationships with pastors and others in their churches. In a couple of instances, informants even reported that they were able to be open with the whole congregation, sharing their stories from the platform, and had even been able to continue in a ministry role, even when the churches they were attending were unable to "affirm" their sexuality. There was one condition: the requirement that they abstain from romantic and/or sexual same-sex relationships, also known as "the line".

While those who were willing to accept the celibacy "line" requirement may have managed to stay, the majority of informants indicated they had made the difficult decision to leave. In this cohort, several who had occupied ministry or volunteering roles feared that their ministries would

1 At the time of writing, I have not interviewed any Intersex informants. 
end if they came out. In a number of cases, these fears were justified, as coming out indeed meant displacement from leadership positions. Further, several LGBTIQ people who left their congregations reported experiencing silencing and loss of formerly supportive communities. However, there were also profound experiences of relief reported.

LGBTIQ people who participate and exercise spirit-empowered ministry in their churches represent a significant theological challenge to Pentecostal-Charismatic Christianity, where spiritual experience is regarded as the primary qualification and authorisation for ministry. Indeed, LGBTIQ people exercising gifted ministry in PCC churches are "impossible subjects"—queer recipients of God's blessing and favour who simply cannot exist in an exclusively heteronormative understanding of Christianity. ${ }^{2}$

It may seem to many within and without PCC that LGBTIQ exclusion is the only option, given the movement's historically literalist reading of some of the apparent prohibitions against same-sex attraction in the Bible. ${ }^{3}$ However, Pentecostal-Charismatic Christians can find inspiration for a different approach through an appreciation of the inclusive history of the movement, particularly in Australia. This is perhaps best demonstrated in the role of early Australian Pentecostal women leaders, who transcended exclusionary interpretations of sacred scripture and church tradition in order to pioneer most of the Australian congregations in the early twentieth century-primarily because it was believed they had been spiritually authorised to minister.

Drawing on the interviews, I argue in this paper that "the line" celibacy requirement is unnecessary and untenable. The egalitarian history of Australian Pentecostalism stands testimony to the possibility of another, more inclusive approach.

\section{Background to the Research}

At the time of writing, 20 in-depth interviews had been completed with LGBTIQ individuals who attend—or formerly attended-PCC congregations, with more interviews anticipated. ${ }^{4}$ In order to compile a sample, the project was advertised via the website of the author's academic institution, and permission was also sought to advertise via the website freedom $2 \mathrm{~b}$, an online community forum for Australian LGBTIQ Christians (Freedom2b n.d.). The author's own networks in the PCC and LGBTIQ communities, as well as snowball sampling whereby I relied on informants to recommend or refer other contacts, proved invaluable. By far the largest response has been from participants who were encouraged by peers to contact the author. ${ }^{5}$ As with nearly all research that passes through university ethics committees, anonymity and de-identification is mandated, and in this case is particularly important. All interviews have been anonymized, and participants are given a gender-neutral pseudonym when they are quoted in this paper.

For the LGBTIQ cohort, a set of indicative questions was put together. The first section consisted of 12 general questions for all participants (Figure 1). The second section of 10 questions was for the

2 This term was coined by Ibrahim Abraham, who recognises queer Australian Muslims as similar impossible subjects-a configuration of sexuality and spirituality 'impossible' in heteronormative understandings of Islam (Abraham 2009). See also (Ngai 2004).

3 The passages often quoted in support of the sinfulness of same-sex attraction and/or relations (as an example of one LGBTIQ issue) are: Genesis 19; Leviticus 18:22 and 20:13; Romans 1:18-32; 1 Corinthians 6:9-10; 1 Timothy 1:9-10; and Jude 6-7. Some LGBTIQ Christians refer to these as "clobber passages," as they have been used in the past to exclude same-sex attracted people from faith and ministry (Gresham 2012; Kirby 2013). In doing this, it is fair to say that several of these texts have been taken out of context, and many have pointed out some of the hermeneutic challenges associated with these passages. Nevertheless, as Wink (1999) has indicated, there are at least three texts in the Biblical canon that appear, when applying sound hermeneutic critique, to unequivocally condemn same-sex romantic and sexual relations. They are Leviticus 18:22; 20:13; Romans 1:18-32: Walter Wink, "Homosexuality and the Bible," in Homosexuality and Christian Faith: Questions of Conscience for the Churches, ed. Walter Wink (Minneapolis: Fortress Press, 1999), 33-49.

4 Interviews will continue until "data saturation": namely, the point at which no new themes or unfamiliar narratives are emerging from interviews is reached. My initial proposal was to complete 20 in-depth interviews with PCC pastors and 30-50 interviews with LGBTIQ participants.

5 This is a qualitative study, employing non-probability sampling, and hence makes no claims to being representative of all LGBTIQ experiences of PCC in Australia. 
cohort no longer attending a PCC church (Figure 2). Finally, the third section of nine questions was relevant to LGBTIQ informants whose attendance and participation in a PCC church were ongoing (Figure 3). Interviews were semi-structured, and often in the course of the interview participants answered questions I had not put to them. This was anticipated, and the questions were purposefully indicative, meaning that questions could be dropped when they were deemed unsuitable or the informant had already addressed them in other answers.

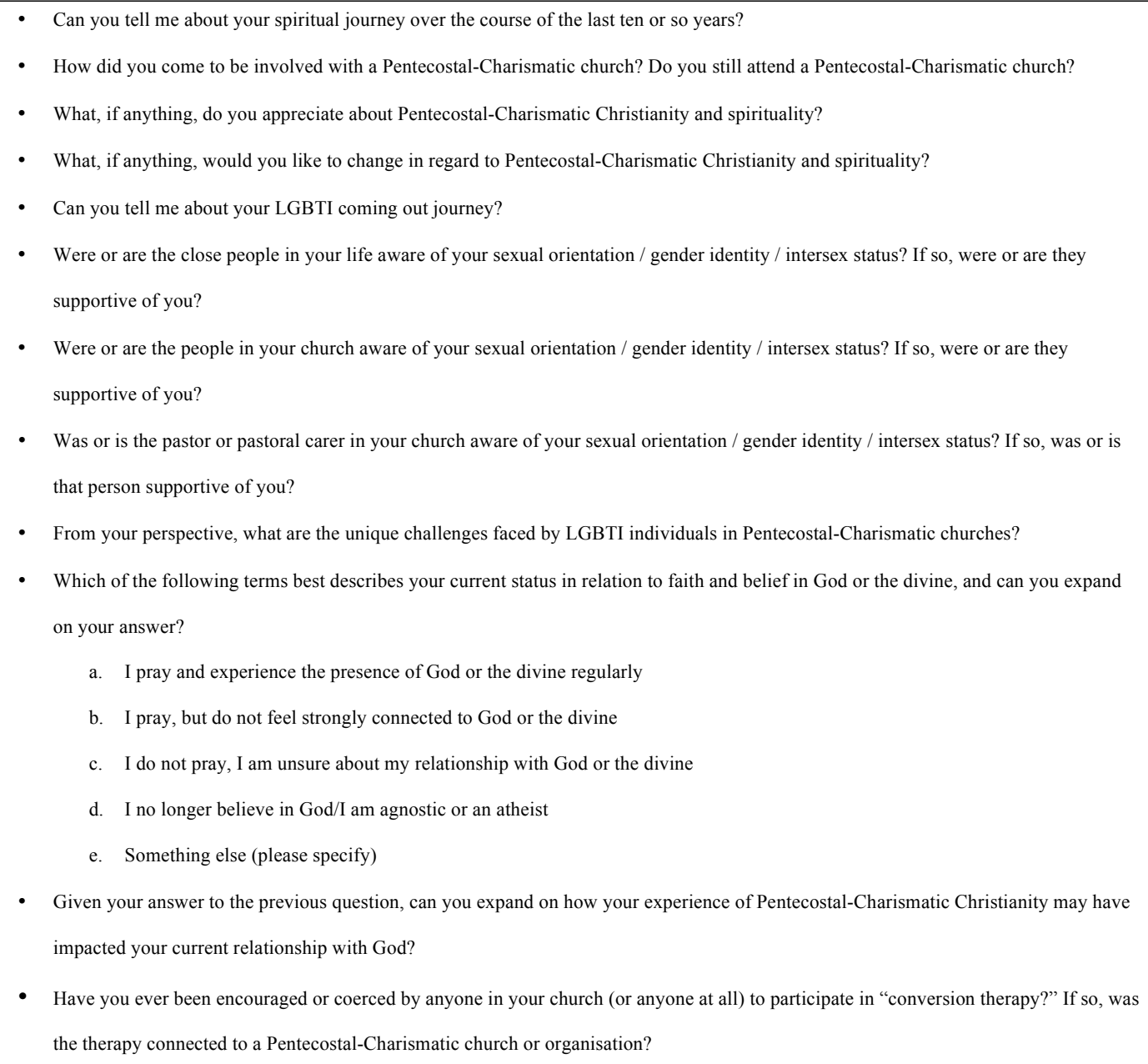

- From your perspective, what are the unique challenges faced by LGBTI individuals in Pentecostal-Charismatic churches?

- Which of the following terms best describes your current status in relation to faith and belief in God or the divine, and can you expand on your answer?

a. I pray and experience the presence of God or the divine regularly

b. I pray, but do not feel strongly connected to God or the divine

c. I do not pray, I am unsure about my relationship with God or the divine

d. I no longer believe in God/I am agnostic or an atheist

e. Something else (please specify)

- Given your answer to the previous question, can you expand on how your experience of Pentecostal-Charismatic Christianity may have impacted your current relationship with God?

- Have you ever been encouraged or coerced by anyone in your church (or anyone at all) to participate in "conversion therapy?" If so, was the therapy connected to a Pentecostal-Charismatic church or organisation?

Figure 1. Indicative interview schedule-general questions for all participants.

For the purposes of writing this paper, I carried out thematic analysis with the assistance of the qualitative analysis software programme NVivo 10. The themes emerging from this analysis pertinent to this paper relate to LGBTIQ peoples' experiences of ministry, remaining in or leaving their PCC churches, and SOCE.

In order to position myself in relation to this research and provide some personal context for this paper, I take this opportunity to declare my own horizons. I am a cisgender, straight male, and I have attended PCC churches most of my life, although I no longer do so. My personal understanding of LGBTIQ people and issues began with ignorance, moving first toward a belief that this phenomenon was real but could not be reconciled with Christianity, and finally to an embracing of both diverse sexualities and the interpretive nature of all approaches to the Bible. I regard myself as an ally of LGBTIQ persons and an advocate for their full inclusion and acceptance in faith communities. 


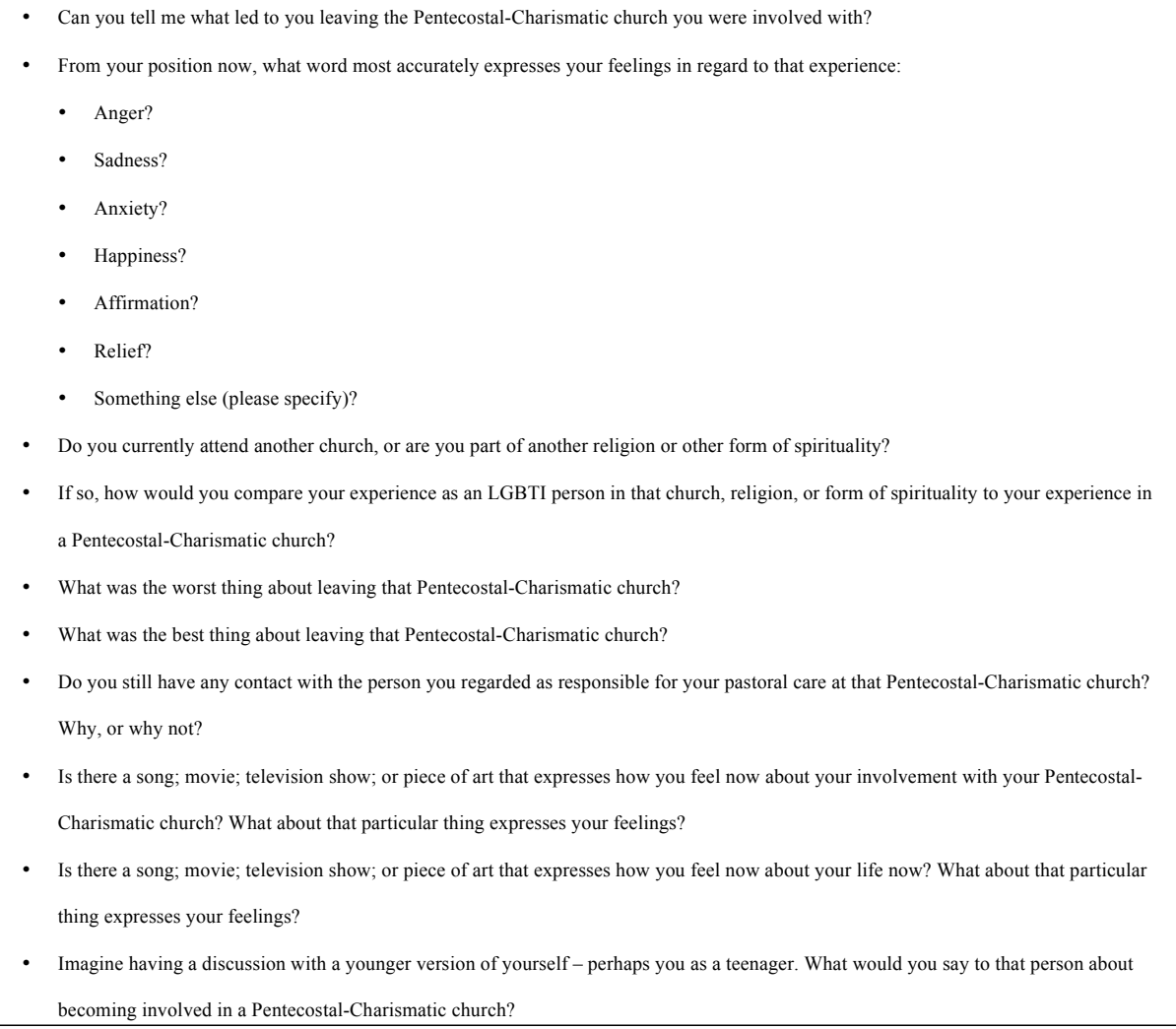

Figure 2. Indicative interview schedule-questions for participants who are no longer attending a Pentecostal-Charismatic Christian (PCC) church.

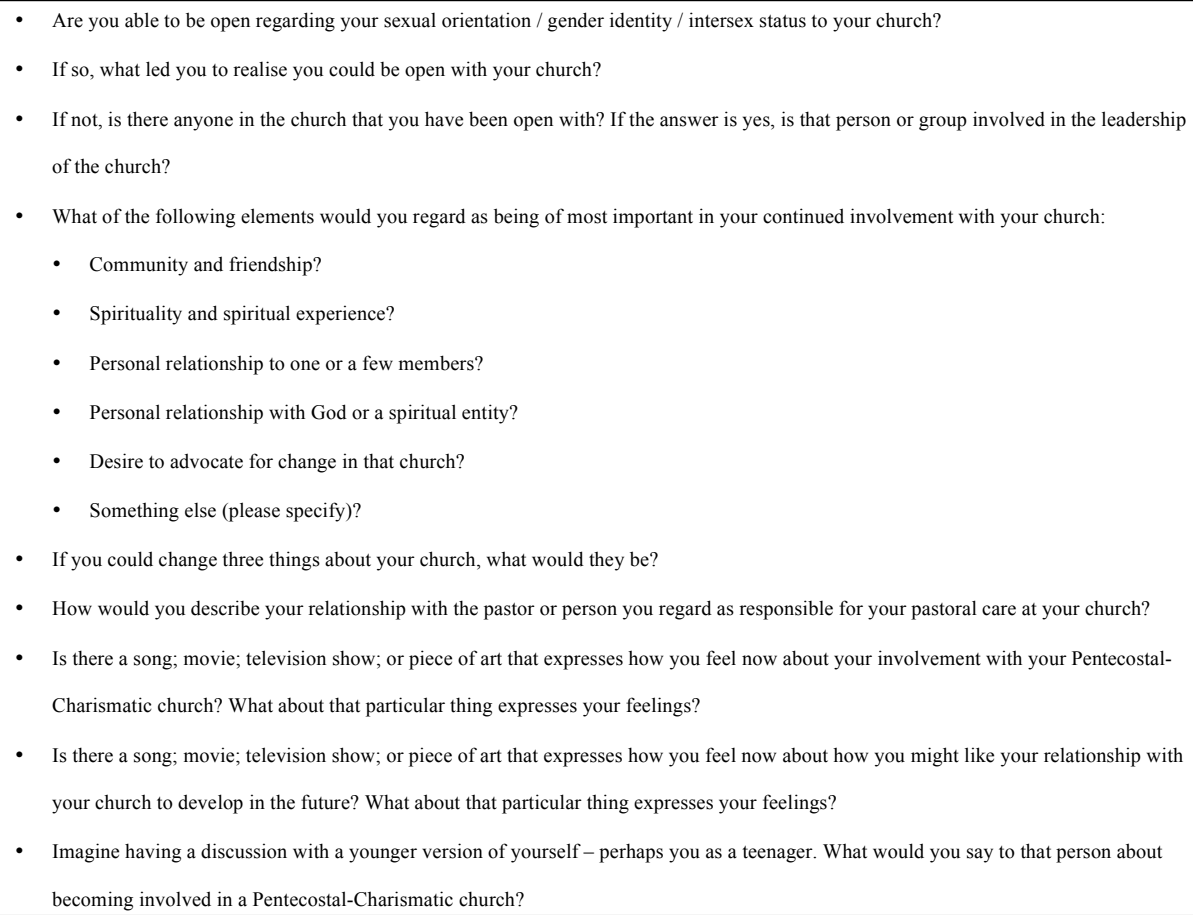

- If you could change three things about your church, what would they be?

- How would you describe your relationship with the pastor or person you regard as responsible for your pastoral care at your church?

- Is there a song; movie; television show; or piece of art that expresses how you feel now about your involvement with your PentecostalCharismatic church? What about that particular thing expresses your feelings?

- Is there a song; movie; television show; or piece of art that expresses how you feel now about how you might like your relationship with your church to develop in the future? What about that particular thing expresses your feelings?

- Imagine having a discussion with a younger version of yourself - perhaps you as a teenager. What would you say to that person about becoming involved in a Pentecostal-Charismatic church?

Figure 3. Indicative interview schedule-questions for participants who are currently attending a PCC church. 


\section{Those Who Stayed: LGBTIQ in Ministry}

Of those LGBTIQ informants who remained in their PCC congregations, some did not make their sexuality known. Yazz, who communicated with me via email, formerly worked as a youth pastor in a PCC church. Yazz's church required that they be in an accountable relationship and attend counseling. ${ }^{6}$ Yazz did not "come out" as LGBTIQ to the church, and as Yazz was not in a romantic relationship until meeting and marrying a person of the opposite gender, it never came up.

About a year into being in the [name redacted] church and at the beginning of being on staff there, I was appointed a female mentor. Part of her role was to keep me accountable with my sexuality. ... I did not participate in any formal conversion therapy but I did see a counsellor for some time that was recommended to me by the church. The counsellor was sought for other reasons but my sexuality certainly came up. She never tried to convert me and encouraged me to explore where I stood with my sexuality.

There were also cases where only the pastor or a few people in the church knew about the informant's status. One transgender participant, Phoenix, felt safe enough to disclose this information to the pastor.

I don't tell people. A situation happened the year I started at [church name redacted] that my pastor was told by people that used to know me, that were trying to get me to change back. ... But he basically stopped and went, "No. You know what? Talk to me. Tell me your story." And I went, "This is it." And he went, "I don't understand it, but I'm not going to reject you. I want you to still stick around the church." There are things, like because I'm not allowed to get up on the pulpit, I'm not allowed to be in the musicians - I can do the sound, but I can't get up and sing, you know, and do those sort of things-but it's a journey for them as much as it is for me.

Phoenix, as a transgender person, did not identify as part of the queer community. ${ }^{7}$ While most of the informants encountered barriers to full participation in their PCC congregations based on sexuality, Phoenix could "pass" for a cisgender person. As indicated in the above quote, Phoenix rarely told people they were transgender, having experienced very negative reactions from PCC people in churches in the past. This came up when Phoenix was asked to suggest what changes should occur in PCC.

If anything, I'd like to change their opinions, at times, in relation to-some of them can be very, I won't say dogmatic - but just take the fact that I'm a transgender, it's the sheer fact that if people find out, suddenly I'm ostracised because of it."

It seems, then, that as long as Phoenix's transgender status remained a secret from all but their pastor, no negative attention was experienced, presumably because other congregants assumed Phoenix was cisgender. However, the pastor did place limitations upon permissible forms of ministry-Phoenix could operate the sound desk, but not participate in up-front platform ministry.

Variations of this limitation, referred to as "the line" by some participants, was a commonly referenced practice aimed at putting conditions on the involvement of LGBTIQ people in PCC ministry. In Xavi's church, LGBTIQ people were welcome in the "foyer" and the "living room," but not in the kitchen, the deepest and most intimate level of membership, where those who volunteer in the church were to be found.

6 Please note that throughout this paper, gender-specific pronouns have been eschewed in favor of the non-gendered "they", "them," or "their," even when referring to singular entities. For the sake of readability, I have endeavoured to keep this to a minimum.

7 Transgender people can be straight, gay, lesbian or bisexual. For instance, a trans man who is attracted only to women would identify as straight. 
So I knew [my former church] like the back of my hand... I had grown up in this place. I had an all-access pass. I had a key to pretty much every door ... It was about the same time [the leader] was identifying the language to use about the church and... [they] kind of had this concept of a foyer space ... a living room space, a kitchen space, and they have different levels of intimacy. So a foyer space is kind of like a weekend service for a guest-type person. Anyone is welcome to the foyer. I think a living room was to do with shared interests. So like a small group. And a kitchen space was, like, very intimate, so your very close group of friends or volunteering or leadership, and things like that. The core was, if you're a practising homosexual (... there was no concept of LGBTI or anything like that ... ) you were welcome but not affirmed. So, "We want you, we love you, and you're welcome, and we want you to come to our church, but effectively that's where it ends. If you want to be part of the church, you ... can be gay, but you have to be celibate" .. That's the line. ${ }^{8}$

LGBTIQ people were only welcome "in the kitchen" - that is, able to exercise ministry and volunteering roles in their churches-if they committed to abstain from romantic and/or sexual relationships with those of their own gender. "The line" has the function of excluding LGBTIQ people from positions of leadership, where they might in time come to exert a more inclusive influence in the congregation, because volunteering is the pathway to leadership in many PCC churches.

In contrast to Phoenix and Xavi, some informants reported being able to be open about their LGBTIQ status with pastors and even the wider congregation, and experienced feeling strongly supported by both. One example is Harley, who described PCC in general as "very, very loving."

I know people who love me deeply, and I feel deeply loved by them, and you know, ... we'll get together and we'll pray and we'll worship and we'll fellowship, and it's beautiful, and the presence of God is so there. And yet if I were to go and get ... romantically involved with another [person of the same gender], like, they would sit down with me and be like, "Hey, what's going on?"

It is important to acknowledge that Harley did not regard their congregation's love and support as conditional, but merely observed that becoming involved in a same-sex relationship would trigger a process of accountability. Harley experienced the congregation as very accepting, noting that no attempt had been made to "fix" Harley's sexuality.

By and large, people have been really accepting and embracing of me as a person and me as a human being, with all of my struggles, and they've been really understanding and really supportive ... I couldn't be happier with the way in which people have journeyed with me, because... it's not been this on the front foot, proactive, hands-on approach where they're trying to fix me and I'm their project of sorts.

Harley reported exercising a recognised ministry role in the church, including offering testimony before the whole congregation. However, Harley was also emphatically committed to remaining celibate, having even attempted (unsuccessfully) to date people of the opposite gender. Harley remained sanguine about the possibility of a future relationship, not being prepared to "limit the power of God."

[God] may very well do a work within my heart and within my mind and within my life that shifts the desires I have, and all of a sudden ... I find one day down the track... I do desire to be with a [member of the opposite sex] and to have a [spouse] and all of that normal stuff that comes with a family.

Harley was not the only informant to express the hope that divine intervention might produce a "shift" in sexual orientation. Gabriele, who also remained within a PCC church and felt highly

8 The phrase "welcome but not affirmed" differentiates churches wherein LGBTIQ people are fully included in church life and ministry from those churches that "welcome" LGBTIQ people, but do not "affirm" their sexuality or gender. The late Stanley Grenz outlined this position in the book of the same name (Grenz 1998). 
supported by the congregation, voiced the same hope. Asked whom specifically in the church they could be open with about sexuality and gender, Gabriele replied as follows:

There's my pastor, my missions pastor, and a few of my good friends in church. They're supportive for my change. They don't-they don't agree with it, and neither do I, so we're all supportive for my transformation and my change... Nobody agrees with this lifestyle, so just to make that clear. Everyone supports my journey of healing, not my journey into it, if that makes sense... So yeah, they're all praying for me to get healing and continue to live a celibate life, and I ... hope to get healed one day.

To clarify, "it" in the above quote refers to same-sex attraction. Gabriele reported having felt same gender attraction for many years, and here indicates that the church is willing to support them-but not "that lifestyle." In other words, Gabriele, the pastor, and the church are praying that Gabriele will be "healed" from same-sex attraction. Like Harley, Gabriele has accepted that, until this happens, adherence to "the line" of celibacy is required.

Again, it would be a misrepresentation to claim that Gabriele felt that the support and love of the pastors and church was conditional. However, corresponding to "the line," both Gabriele and Harley were only able to continue exercising ministry roles so long as they remained celibate, and both aspired to a shift in orientation. Be that as it may, the support and care that Harley and Gabriele, among others, experienced contrasts sharply with the treatment reported by those who ended up leaving their PCC congregations.

\section{The Devil Made You Do It: PCC and SOCE}

Another informant, Fain, related leaving their home church and joining another one, in part because of confusion and fear over coming out. Following the decision to come out, and upon returning to the original congregation, Fain was called to the pastor's office for a discussion. The pastor was blunt in assessing what had happened to Fain at the other church.

[My pastor said] that I had been deceived by the devil and followed a false prophet ... that I had then been convinced that I was a homosexual and chosen to live a sinful lifestyle, and that if I wanted to have any active part in leadership or in the church, I had to repent, and either go through therapy or be celibate for the rest of my life.

Iva described the trauma of being convinced that their sexuality-something deeply integral to one's identity—was attributable to demonic possession or influence.

When my awareness around my sexuality came up, I was in deep, deep trauma ... I really split myself between my belief in a God that I believed was all-powerful and connecting to an amazing community that I was within, whilst at the same time I had a deep, deep, deep, dark, hidden secret-which, through teaching at [Church name redacted], was attributed to Satan, demons, the devil, and evilness. So I constructed for myself a really big sort of duality of good and evil.

Iva's experience reflects a PCC view of the body, one which is complex and seemingly contradictory at times. Michael Wilkinson has argued that, in Pentecostal thought, the body can be perceived as "a site for a type of battle that manifests through interpretations of good and evil that require Pentecostals to control evil spirits" (Wilkinson 2017). This has implications for understanding PCC attitudes to LGBTIQ people. While it might be easy to dismiss exclusionary attitudes as simply uninformed or bigoted, it is important to remember that a particular set of PCC understandings of the body and sexuality mean that many PCCs would regard advocating healing or exorcism as a compassionate approach toward people whose bodies are believed to have been possessed by malign forces, whether of illness or demonic possession or both. One of the purposes of the research presented in this paper is to indicate what such understandings do to LGBTIQ people themselves.

Fain and Iva were not alone in having their same-sex attraction blamed on demonic influence. Phoenix, when asked whether or not "conversion therapy" (a form of counseling aimed at "converting" 
participants from LGBTIQ to heterosexual) had ever been suggested or mandated, related a similar incident.

Interviewer: The next question is, have you ever been encouraged or coerced by anyone in your church, or anyone at all, to participate in conversion therapy?

Phoenix: No. The only thing I can say is when I . . before transition, when I was going to [Church name redacted], I had—one of the pastors there believed I had a demonic spirit in me for homosexuality and tried to pray it out of me.

Conversion therapy—also known as "ex-gay therapy" or "reparative therapy" —is regarded as highly controversial in Australia. However, some congregations unofficially offer "counseling" or group work programmes to LGBTIQ people, such as Living Waters or Exodus, which are described as targeting "addiction." " Some participants defended SOCE programmes. Gabriele, who had positive experiences of these two programmes, objected to the term "conversion therapy."

Interviewer: So, have you ever been encouraged or coerced by anyone, either in your church, or anybody at all, to participate in conversion therapy?

Gabriele: What's conversion therapy?

I: So conversion therapy, or ex-gay ministry, sometimes it's called, is a ministry that is aimed at helping people transition or change their sexual preference or identity.

G: Well, that's what counseling is. When you go to a Christian counselor you can expect that they're going to help you walk with Jesus, so not to be a homosexual. To be the opposite.

I: Mm, hmm. And you mentioned-

G: Whatever the opposite is for you, whether it's heterosexual or not. Whether that's heterosexual or not, you just can't be homosexual. So I wouldn't call that conversion therapy.

I: You wouldn't call it conversion therapy. Okay. You mentioned Exodus and Living Waters. Can you tell me a bit more about your experience of those?

G: They're fantastic. They bring in the Holy Spirit, the word of God. They don't directly say, you know, you have to be a certain way, they just basically lead you and guide you by the Holy Spirit how to live with Jesus, and whatever addiction you have, whether it's sexual or not-you can put yourself in there quite safely.

For Gabriele, the focus of the SOCE programmes is therefore addiction rather than conversion, with the proviso that the purpose of the therapy is to render one the "opposite" of homosexual. Gabriele articulates the view of many conservative PCCs in stating, "you just can't be homosexual."

As an LGBTIQ person who remained within a PCC congregation, Gabriele also speaks positively of the community offered by these SOCE programmes, which provided a high level of support and identification.

So you're in small groups, and you get to share your own personal testimonies. And everyone did it when I did it, which was nice, because then you realised, "Oh, I'm not that different to others" ... Even though I struggle with this, they struggle with that, and so we could all support one another.

9 The Australian arm of Living Waters officially ceased operations in 2014, and Exodus International officially ceased operations in 2013 (Venn-Brown 2014; Payne 2013). However, as Venn-Brown indicates, there remain a "handful of organisations" offering SOCE in Australia, possibly using the same methods and approaches as Living Waters and Exodus (Venn-Brown 2015). 
Gabriele's description corresponds with Bernadette Barton's participant observation at the 2009 Exodus International conference. Barton notes that the conference was a unique space in which attendees did not need to conceal the fact that they were gay, where "[n]obody—not their conservative Christian family members or gay friends-was allowed them to give them a hard time." It was a brief time and space where they did not have to hide, and there was "something freeing about that" (Barton 2012).

Graham Douglas-Meyer, pastor of the affirming Open Arms Fellowship, a PCC church in Perth, Western Australia, is highly critical of SOCE. However, Douglas-Meyer expressed observations similar to Barton's in relation to the "Genesis" programme, an outreach of Exodus International.

I found the group to be quite encouraging. For the first time in ten years I was working alongside other young men who were facing a similar struggle to my own and who also wanted to do something about it. I made some good friends without the need for sexual intimacy. (Douglas-Meyer 2014)

While these descriptions of group work and counseling in Living Waters and Exodus are somewhat positive, there are other reports of less edifying encounters with SOCE. Anthony Venn-Brown, a former Pentecostal minister and ex-gay survivor, has tracked the changes in terminology and language being generated by SOCE ministries and organisations in Australia. In the early stages, when instant cures and exorcisms were still commonly offered, SOCE was described as "freedom from homosexuality." As it became clearer that instant cures were not the normal experience, SOCE language moved to dealing with "unwanted same-sex attractions." Most recently, the language has become even more inclusive, with reference to sexual or relational "brokenness" - phenomena that any Christian, or indeed any individual, may experience, regardless of gender or sexuality. Venn-Brown remains skeptical of SOCE.

[T]his kind of terminology is an attempt to make the message more palatable to the seeker of help and as a defence to those opposing SOCE work... the underlying message remains the same_- "homosexuals are broken people and God can fix them." (Venn-Brown 2015)

Venn-Brown's and Douglas-Meyer's experiences of SOCE are part of the limited, but very significant, autobiographical works of Australian LGBTIQ people who identify or formerly identified as PCC. While living in New Zealand, Australian author Jim Marjoram participated in the Living Waters 26-week course on numerous occasions, both as a "worship leader" (that is, someone who coordinates music and leads participants in singing praise and worship music, a highly significant part of PCC spirituality) and leading small groups (Marjoram 2017). Marjoram makes the important observation that commitment to celibacy, rather than insisting that one is "cured" of same-sex attraction, may actually be a healthier state of being for participants in SOCE.

It [Living Waters] all produced endless introspection and confession, and a religious obsession that starts to get really uncomfortable and detached from reality... There are smiles and laughs, but underneath it all is a heavy intensity that slowly keeps piling up guilt and shame, or should I say slowly repressing overt guilt and shame until unreality sets in, often resulting in depression and a constant nagging that you can never live up to God's standard, eventually creating a far more serious and deeper dissonance than before, with absolutely no hope of being yourself or living with personal integrity. It effectively shuts down the most basic and fundamental parts of our makeup behind a wall of religious activity... Without exception, every person who I have spoken to or observed, claiming to be transformed, simply denies that there is a problem anymore, even though they still have to wrestle with same sex attraction... There are some who have a semblance of honesty and just refuse to act on their inherent sexuality, claiming celibacy is the only option, until they have achieved the magical goal of becoming straight, if ever. Most however, delegate their same sex attraction to the same basket as any sinful thought, and keep repenting and standing on God's apparent promises of healing. (Marjoram 2017) 
As these accounts make clear, some LGBTIQ PCCs regard their options as either lifelong celibacy or possible healing via SOCE, since in their understanding of their faith, it is simply impossible to be both queer and Christian. For Hollis, the choice was no choice at all—seek conversion therapy, with the promise of a heteronormative life with a spouse, family, and ministry, or come out and lose God and church.

I wish I'd known then that you could be gay and Christian, and I wish I'd known other people and other stories that had communicated that to me. Because for me, it was come out and lose God, lose your friends, lose hope, lose a good life, or don't come out, try to change, go through this stuff, and you can still keep God, you can still keep your church, you can still keep your friends. You may have a [spouse] one day, you may have kids one day ... It was definitely my choice, but at the same time it was kind of like, you know, what other choice did I have? ... I wish that churches-even though I know they don't do this now - but I wish that churches could offer almost like a balanced view ... I would hope that churches don't recommend that anyone do conversion therapy or ex-gay programs or anything like that now. I hope that that doesn't happen. But I think if they were to offer a view and say, "Yeah, you can be gay and Christian, and we support you, and we want to encourage you in your faith regardless of if you're gay or straight," I think that would be so much more helpful.

If any indication were needed that the LGBTIQ people who participate in PCC churches (as well as other Christian denominations that have endorsed SOCE in the past) have a genuinely held faith, we need look no further than the experiences of those like Hollis who went to extraordinary lengths to try to change. ${ }^{10}$ In the end, Hollis was one of several informants who, after trying hard via SOCE to "be straight," ended up leaving PCC.

\section{Those Who Left: Able to Breathe}

Several informants reported a crisis wherein they felt they could no longer remain closeted, but at the same time feared being open would lead to loss of formerly supportive communities and ministries. Often, they made the wrenching decision to leave their churches.

One example was Fain, who exercised a recognised healing ministry in a PCC church. However, coming out as gay ended Fain's ministry.

There are so many other accounts where I've been in churches and laid hands on the sick and seen supernatural healing come to people, and medically verified. One lady had cancer. It ... was bladder cancer, and it got to the point that it had rapidly spread to ... other parts of her body... It was a long, long time, probably over a year, that we were praying for her. And she came straight to me, because in the church environment, these sort of encounters weren't happening for anybody else, but they were happening for me.

So I was essentially put on a pedestal, and put on the, on a prayer team, and put on the leadership team in outreach, and put on-even if that was short-lived, because I came out of the closet (laughs).

Another example was Xen, who prior to coming out was a volunteer in a church-based children's ministry. However, after Xen came out, this ministry ceased.

I think the biggest challenge is fighting for who you are, you constantly feel like you are not good enough to be there and no longer do people look at you the way they once did. I was no longer allowed on kid's ministry. I couldn't talk to the youth about it; I couldn't share my struggles because I "refused" to change. But, an adulterer, porn addict, an ex-drug addict and ex-prostitute could. They could even get on stage and share about their experiences, but not me. I had to be quiet. That's

10 Mark Henrickson makes a similar point, praising the resilience of LGBTIQ people in remaining faithful to traditions that have in many cases abandoned them (Henrickson 2007). 
the battle: Not only are you fighting in your own head, but you are fighting an entire belief system that has previously told you, you are loved and that God will meet you wherever you are at.

Xen's description suggests that the situation was traumatic for some in the congregation as well, who experienced Xen's honesty not as authenticity, but as a refusal to change. Xen experienced this as being silenced, left unable to share authentically, because of this perceived refusal to accept the sinfulness of queer sexuality.

Several informants reported agonising, sometimes for years, over this dilemma, having internalised the belief that their sexuality or gender was sinful and wrong. Xen was one who was able to find friends to confide in about the struggle.

I started to talk to some really good and trustworthy friends of mine who were incredible, and to this day I owe them my sanity. They would tell me that I was amazing, loved, and that my sexuality didn't mean I was a bad person. But no matter how hard I tried, I couldn't admit it. The fact was, Christianity told me it was "wrong," "sinful" and "not what God intended for me." I hurt, thinking I was hurting God. Whilst talking to my friends, I would cry, get choked up and become so enraged with myself for feeling this way! I wanted to be straight so bad. But I was realising that it just was not who I was.

Xen's experience of shame and guilt is not unique. Research has indicated that LGBTIQ Christians internalise "homonegativity" - judgments and feelings of shame and guilt about their sexuality or gender-more often than non-Christian LGBTIQ people (Sowe et al. 2014). Many want to "be straight so bad" that it literally makes them unwell. Several informants indicated that they had experienced suicidal thoughts and the desire to self-harm.

It is perhaps unsurprising, then, that some LGBTIQ informants reported a profound sense of relief-along with other emotions, such as sorrow or anger-upon coming out and leaving their PCC churches. When asked what the best thing about leaving was, Yule vividly expressed this sentiment.

It was actually being able to breathe, and ... for me, it was like having my head underwater my whole life and then finally being able to gasp for air, and finally just fill my lungs with air and breathe, and just finally breathe.

Several informants reported finding more homopositive forms of church or faith. Some of those who maintained a Christian faith post-PCC, such as Yazz, related that negative experiences in church-based relationships continued to affect their self-image and relationship with God.

I had become a Christian and was sure God loved me and was with me, but I guess this created doubt over the years of hearing it, and I never really bought into the fact that Christians loved gay people as much as they said when they said things like "Hate the sin not the sinner." Being who I knew myself to be on the inside, I doubted people would love me as much if they knew, and that they would focus on trying to change me if I said anything. I lost a couple of close friendships when I did try, and all this chipped away at how God might view me. I know better now and am comfortable with myself, but I do the feel the loss of the divine relationship I once had. I don't blame that primarily on being part of a PCC church, but it has played a part.

Most informants indicated that they no longer attended a PCC church, and in some cases, they reported having lost their faith entirely. This is reflective of the trend among Australian LGBTIQ people in general: according to the 2005 Private Lives survey, LGBTIQ people are more likely than the rest of the population to identify as "no religion," and also more likely to change their religious affiliation from the faith they grew up in to no religion (Couch et al. 2008; Hillier et al. 2008).

\section{Pentecostalism and LGBTIQ in Australia}

It might surprise many to learn of the egalitarian and inclusive roots of Australian Pentecostalism, which celebrated the pioneering ministry of women before other forms of Christianity "caught up." 
It is beyond the scope of this paper to develop a fully-fledged inclusive PCC theology, but in this section, I will argue that the egalitarian history of the movement in Australia offers another way forward in relation to LGBTIQ people and issues.

One of the most striking things about nascent Pentecostalism, both in the United States and in Australia, was its openness to the ministry of those excluded from leadership in other forms of faith. Perhaps the most celebrated pioneer of the movement was the African-American William Seymour, pastor of the Azusa Street Mission in Los Angeles, California, when the congregation first experienced the "baptism in the Holy Spirit" in 1906 (Wacker 2001; Hollenweger 1997). ${ }^{11}$ Australian PCC's inclusive theological and ecclesiological foundations are rooted in a number of what Shane Clifton has referred to as "voluntarist" religious movements that emerged in the nineteenth century (Clifton 2009). Tanya Riches has uncovered the existence of an Aboriginal-led Pentecostal congregation in Innisfail, Queensland, as early as 1904, starting as an offshoot of the Welsh Revival (Riches 2016).

In a similar vein, Pentecostalism and its antecedents celebrated the ministry of women perceived to have experienced the empowerment of Holy Spirit baptism. As early as 1859, American evangelist and co-founder of the Holiness movement Phoebe Palmer published an apology for the ministry of women, arguing on the basis of the second chapter of the New Testament book of Acts for the egalitarian nature of the baptism in the Holy Spirit (Dayton 1987). In Australia, Sarah Jane Lancaster experienced this blessing, and opened Good News Hall in Melbourne on New Year's Eve, 1909. Lancaster thus became the foundation leader of what has, until recently, been regarded as the first Pentecostal congregation in Australia. ${ }^{12}$ By 1930, more than half the Pentecostal congregations in Australia had been started by women (Chant 2000). Chant writes as follows on the empowering of female ministers by Holy Spirit in the early days of the Australian movement:

\section{It was the coming of the Spirit that commissioned people for ministry — and He was coming not only to men, but to women, too. So ordination was no longer a gender issue. If God Himself had anointed someone with the Spirit, what further endorsement did they need? (Chant 2000) ${ }^{13}$}

Sadly, this progressive beginning appears not to reflect the status of PCC women in ministry in contemporary Australia-not at least if the executive board of Australia's largest Pentecostal denomination, the Australian Christian Churches, is any indication. That board lists eight men and only one woman among its members (Australian Christian Churches 2014). Clifton suggests that early Pentecostalism, restorationist in orientation, was "grounded in a first century ideal," seeking to return to the church of the New Testament and thus adopted a cultural and social conservatism that was believed to reflect first century norms (Clifton 2009).

While this restoration orientation, together with a traditionally literalist interpretation of the Bible, may arguably support the exclusive positions many PCC pastors and churches take in regard to LGBTIQ people and ministry, those positions are complicated by the strong emphasis in PCC on spiritual experience. Traditionally, authorisation for ministry in PCC congregations is not formal

11 Other than Seymour, the individual most often cited as the pioneer of Pentecostalism in the United States is Charles Fox Parham, founder of Bethel Bible School in Topeka, KA, where Agnes Ozman first exhibited glossolalia on New Year's Day, 1901. Parham's legacy is complicated, particularly in terms of this paper, as he was arrested in 1907 on charges of sodomy. The charges were dropped, and Parham always insisted that he had been framed. Walter Hollenweger's comment is worth noting: "It seems to me that, until further evidence is presented, Parham should be considered as having been 'not guilty as charged.' Furthermore, the Parham story (and other similar stories) might sometime stimulate Pentecostals to theologically re-examine their approach to homosexuality, especially in the light of newer theological and medical evidence" (Hollenweger 1997).

12 Apart from the aforementioned Aboriginal-led Pentecostal congregation in Innisfail, which predates Good News Hall, recent research by Peter Elliott indicates that the antecedents of Australian Pentecostalism should be traced to the arrival of representatives of Edward Irving's Catholic Apostolic Church (a Christian group who embraced the "charismatic gifts") in Melbourne in 1853 (Elliott 2012).

13 It is also important not to paint too rosy a picture of Pentecostal acceptance of women in ministry. As Grant Wacker has pointed out, with reference to the American context, such "roseate portraits" can minimize the sociological and theological challenges many women had to negotiate in the early days of the movement (Wacker 2001). 
ordination but spiritual experience, perceived to have its source in God's Holy Spirit (Clifton 2009; Dayton 1987). Such spiritual experiences often take the form of ecstatic phenomena, such as glossolalia, prophecy or inspired speech, healing, and the ability to exorcise evil spirits. The social and cultural norms may have remained patriarchal and Eurocentric, and older, more entrenched forms of Christianity represented these norms. However, in the understanding of the early Pentecostals and some of their antecedents, the "latter rain" Holy Spirit empowerment occurring in the early twentieth century transcended merely human barriers. This helps to explain the flourishing ministries of women and formerly excluded ethnic minorities in the movement's early days.

Returning to the theme of this paper, the interviews quoted herein demonstrate that LGBTIQ Christians in PCC churches have had experiences and exercised gifts believed by their PCC peers to have their source in God's Holy Spirit, just as early Australian PCC women did. LGBTIQ people can reasonably argue that, as God does not render them straight or cisgender in this empowering action-any more than early PCC women were transformed into men-it follows that divine authorisation is not contingent on gender or heteronormativity. Just as this divine authorisation was recognised in the early days of the movement as demonstrating the inclusion of women and ethnic minorities in God's new work, so LGBTIQ people exercising spiritually empowered and authorised ministry in PCC churches may suggest a future direction that is both more inclusive and closer to the spirit of the early PCC movement (Jennings 2017).

\section{Opening up about PCC and LGBTIQ Members}

The interviews quoted in this paper indicate that the presence of LGBTIQ people in PCC congregations remains a vexed issue for PCC churches. Several informants expressed grace and gratitude toward their congregations for offering them a level of acceptance. Harley, for instance, was even prepared to concede that it was tougher on the congregation than on him.

I've had my challenges, but it's been in some ways, I think, more challenging for those around me to know how to counsel me, how to walk with me, how to shepherd me, how to love me appropriately in the midst of it all.

By and large, however, this has not been the case. Many LGBTIQ PCCs have agonised over their sexuality, believing that they would face rejection, the end of their ministry, and loss of community if they chose to be open about their status. In several cases, these worries were justified. Those who remained-even in supportive churches-reported experiencing a dilemma straight cisgender Christians never have to deal with: remaining in an environment where every possible expression of their authentic sexuality is regarded as sinful (Vines 2014).

The injustice of this situation is especially acute in cases where PCC congregations have benefitted from the gifted ministry of LGBTIQ people in their midst. This is demonstrated in the story of Zan.
And I looked for a church for a year, and then in Easter 2011, I played piano at a church, [Church name redacted] ... I was asked there by the pastor's wife, and she was also a worship leader, and I've been playing piano there ever since. I was on the board of the church for a while there as well. They knew I was gay from the start. But then, when I explained to them that I'm prepared to date, I think that ... frazzled them a tiny bit. And then they actually asked me if I could share my story recently, so a month ago I actually shared in church, and in that experience they asked me to step down from the board so it wasn't too confronting for members if they got upset.

Although the church was aware of Zan's LGBTIQ status, Zan was permitted to play piano in the church. Problems began when Zan indicated openness to dating, breaching the celibacy line. Once again, it is evident that Zan and similarly spiritually gifted LGBTIQ people are simply "impossible subjects" in the heteronormative construal of faith which is currently hegemonic in Australian PCC.

This does not need to be the end of the story, however. It remains a hallmark of PCC theology that spiritual empowerment from God is the main authorisation for ministry. If, as indicated here, 
several LGBTIQ people in PCC churches are believed to have had this experience of empowerment and authorisation, and have exercised ministries in their churches on the basis of it, this fact presents a clear and present theological challenge to those who worship in PCC churches-LGBTIQ and non-LGBTIQ alike. The egalitarian history of Australian PCC points to the possibility of another, more inclusive, approach to this challenge, one that celebrates LGBTIQ people exercising ministries in PCC.

Conflicts of Interest: The author declares no conflicts of interest.

\section{References}

Abraham, Ibrahim. 2009. 'Out to get us': Queer muslims and the clash of sexual civilisations in Australia. Contemporary Islam 3: 79-97. [CrossRef]

Australian Christian Churches. 2014. Available online: http://www.acc.org.au/about-us/ (accessed on 7 December 2017).

Barton, Bernadette. 2012. Pray the Gay Away: The Extraordinary Lives of Bible Belt Gays. New York: NYU Press.

Chant, Barry Mostyn. 2000. The Spirit of Pentecost: The Origins and Development of the Pentecostal Movement in Australia 1870-1939. Lexington: Emeth Press.

Clifton, Shane. 2009. Pentecostal Churches in Transition: Analysing the Developing Ecclesiology of the Assemblies of God in Australia. Leiden and Boston: Brill.

Couch, Murray, Hunter Mulcare, Marian Pitts, Anthony Smith, and Anne Mitchell. 2008. The religious affiliation of gay, lesbian, bisexual, transgender and intersex Australians: A report from the private lives survey. People and Place 16: 1-11.

Dayton, Donald W. 1987. Theological Roots of Pentecostalism. Peabody: Hendrickson Publishers.

Douglas-Meyer, Graham. 2014. You Shall Walk in the Dark Places: My Story—Resolving My Sexuality and My Faith. Beeliar: The Love of God Publishing.

Elliott, Peter. 2012. Nineteenth-century Australian charismata: Edward Irving's legacy. Pneuma 34: 26-36. [CrossRef]

Freedom2b. n.d. Available online: https:/ / freedom2b.org/ (accessed on 18 July 2016).

Grenz, Stanley James. 1998. Welcoming but Not Affirming: An Evangelical Response to Homosexuality. Louisville: Westminster John Knox Press.

Gresham, Benny. 2012. Breakfast with Brian: Hillsong, Homosexuality and the Future. Available online: http://bennygresham.blogspot.com.au/2012/05/breakfast-with-brian-hillsong.html (accessed on 19 January 2018).

Henrickson, Mark. 2007. A queer kind of faith: Religion and spirituality in lesbian, gay and bisexual New Zealanders. Aotearoa Ethnic Network (AEN) Journal 2: 6.

Hillier, Lynne, Anne Mitchell, and Hunter Mulcare. 2008. 'I couldn't do both at the same time': Same sex attracted youth and the negotiation of religious discourse. Gay E Lesbian Issues and Psychology Review 4: 80-93.

Hollenweger, Walter J. 1997. Pentecostalism: Origins and Developments Worldwide. Peabody: Hendrickson Publishers.

Jennings, Mark. 2017. A silence like thunder: Pastoral and theological responses of Australian pentecostal-charismatic churches to LGBTQ individuals. In Annual Review of the Sociology of Religion: Pentecostals and the Body. Edited by Wilkinson, Michael and Peter Althouse. Leiden and Boston: Brill, pp. 217-38.

Kirby, Michael. 2013. Clobbering Religious Gay Prejudice. Available online: https:/ /www.eurekastreet.com.au/ article.aspx?aeid=36395 (accessed on 19 January 2018).

Marjoram, Jim. 2017. It's Life Jim ... One Man's Story of "Coming out:" Unravelling Religion, Sexual Identity and Personal Integrity, 3rd ed. San Bernadino: James Marjoram.

Ngai, Mae. 2004. Impossible Subjects: Illegal Aliens and the Making of Modern America. Princeton: Princeton University Press.

Payne, ed. 2013. Group Apologizes to Gay Community, Shuts Down 'Cure' Ministry. Available online: http:/ / edition.cnn.com/2013/06/20/us/exodus-international-shutdown/index.html (accessed on 20 January 2018). 
Riches, Tanya Nicole. 2016. (Re)imagining Identity in the Spirit: Worship and Social Engagement in Urban Aboriginal-Led Pentecostal Congregations. Ph.D. dissertation, Fuller Theological Seminary, Pasadena, CA, USA.

Sowe, Babucarr J., Jac Brown, and Alan J. Taylor. 2014. Sex and the sinner: Comparing religious and nonreligious same-sex attracted adults on internalized homonegativity and distress. American Journal of Orthopsychiatry 84: 530-44. [CrossRef] [PubMed]

Venn-Brown, Anthony. 2014. Living Waters Australia to Close. Available online: http:/ /www.abbi.org.au/2014/ 03/living-waters-australia/ (accessed on 23 August 2017).

Venn-Brown, Anthony. 2015. Sexual orientation change efforts within religious contexts: A personal account of the battle to heal homosexuals. Sensoria: A Journal of Mind, Brain $\mathcal{E}$ Culture 11: 81-91.

Vines, Matthew. 2014. God and the Gay Christian: The Biblical Case in Support of Same-Sex Relationships. New York: Convergent Books.

Wacker, Grant. 2001. Heaven below: Early Pentecostals and American Culture. Cambridge: Harvard University Press. Wilkinson, Michael. 2017. Pentecostalism, the body, and embodiment. In Annual Review of the Sociology of Religion: Pentecostals and the Body. Edited by Wilkinson, Michael and Peter Althouse. Leiden and Boston: Brill, pp. 17-35.

Wink, Walter, ed. 1999. Homosexuality and the bible. In Homosexuality and Christian Faith: Questions of Conscience for the Churches. Minneapolis: Fortress Press, pp. 33-49.

(C) 2018 by the author. Licensee MDPI, Basel, Switzerland. This article is an open access article distributed under the terms and conditions of the Creative Commons Attribution (CC BY) license (http:/ / creativecommons.org/licenses/by/4.0/). 